\title{
Cloning, Characterization, and Chromosomal Mapping of Human Aquaporin of Collecting Duct
}

\author{
Sei Sasaki, * Kiyohide Fushimi, * Hideyuki Saito," Fumiko Saito," Shinichi Uchida, * Kenichi Ishibashi, * Michio Kuwahara, * \\ Tatsuro Ikeuchi," Ken-ichi Inui," Kiichiro Nakajima," Takushi X. Watanabe," and Fumiaki Marumo* \\ ${ }^{*}$ Second Department of Internal Medicine, ${ }^{\ddagger}$ Department of Hospital Pharmacy, School of Medicine, and ${ }^{\S}$ Department of Cytogenetics, \\ Medical Research Institute, Tokyo Medical and Dental University, Tokyo 113; and "Peptide Institute Inc., Protein Research Foundation, \\ Minoh, Osaka 562, Japan
}

\begin{abstract}
We recently cloned a cDNA of the collecting duct apical membrane water channel of rat kidney, which is important for the formation of concentrated urine (Fushima, K., S. Uchida, Y. Hara, Y. Hirata, F. Marumo, and S. Sasaki. 1993. Nature [Lond.]. 361:549-552). Since urine concentrating ability varies among mammalian species, we examined whether an homologous protein is present in human kidney. By screening a human kidney cDNA library, we isolated a cDNA clone, designated human aquaporin of collecting duct (hAQP-CD), that encodes a 271-amino acid protein with $91 \%$ identity to rat AQP-CD. mRNA expression of hAQP-CD was predominant in the kidney medulla compared with the cortex, immunohistochemical staining of hAQP-CD was observed only in the collecting duct cells, and the staining was dominant in the apical domain. Functional expression study in Xenopus oocytes confirmed that hAQP-CD worked as a water channel. Western blot analysis of human kidney medulla indicated that the molecular mass of hAQP-CD is $29 \mathrm{kD}$, which is the same mass expected from the amino acid sequence. Chromosomal mapping of the hAQP-CD gene assigned its location to chromosome 12q13. These results could be important for future studies of the pathophysiology of human urinary concentration mechanisms in normal and abnormal states. (J. Clin. Invest. 1994. 93:1250-1256.) Key words: vasopressin • urinary concentration • diabetes insipidus • kidney medulla $\bullet$ water channel
\end{abstract}

\section{Introduction}

Among animals, only mammals and birds can produce urine hypertonic to the plasma. Concentrating urine is necessary to prevent water loss, and this is required for living in a terrestrial environment (1). In response to vasopressin, concentrated urine is produced by water reabsorption across the kidney collecting duct. Water is thought to pass through water-permeable pores, i.e., "water channels," in the apical membrane of this nephron segment (2-7). We recently cloned a cDNA of the apical collecting duct water channel of the rat kidney (8), based on the conserved amino acid sequence in the members of

\footnotetext{
Address correspondence to Dr. Sei Sasaki, Second Department of Internal Medicine, Tokyo Medical and Dental University, 1-5-45, Yushima, Bunkyo-Ku, Tokyo 113, Japan.

Received for publication 30 July 1993 and in revised form 10 November 1993.
}

J. Clin. Invest.

(c) The American Society for Clinical Investigation, Inc.

$0021-9738 / 94 / 03 / 1250 / 07 \$ 2.00$

Volume 93, March 1994, 1250-1256 the major intrinsic protein (MIP) ${ }^{1}(9)$ family, including channel integrate protein of $28 \mathrm{kD}$ (CHIP28), a water channel of red blood cells, and renal proximal and descending tubules (10-12). This protein was initially reported as the water channel of collecting duct and subsequently renamed aquaporin of collecting duct (AQP-CD). Rat (r)AQP-CD is a 271-amino acid protein with $43 \%$ amino acid identity to CHIP28. It has six putative membrane spanning domains, internal tandem repeat, and conserved NPA box (Asn, Pro, Ala, sequence); all these are characteristics of the MIP family $(13,14)$. Immunohistochemical study using polyclonal antibody against rAQPCD showed that this protein was expressed only in the collecting duct, and the staining was strong in the apical and subapical regions. Injection of in vitro transcribed $m R N A$ of $r A Q P-C D$ to Xenopus oocytes induced a more than eightfold increase in water permeability compared with water-injected oocytes. This induction of water permeability was inhibited by a water channel inhibitor, $\mathrm{HgCl}_{2}$. All these results suggest that $\mathrm{rAQP}-\mathrm{CD}$ is the vasopressin-regulated water channel of the kidney collecting duct (8).

There are species differences in urine concentrating abilities of mammals. For example, humans can concentrate urine to $1,400 \mathrm{mOsm} / \mathrm{kg}$, whereas rats concentrate it to $2,600 \mathrm{mOsm} /$ $\mathrm{kg}$, and Australian hopping mice can concentrate it as high as $9,000 \mathrm{mOsm} / \mathrm{kg}$ (15). Histological studies have also shown that there are distinct morphological differences among medullary structures of mammals (16). Furthermore, biochemical studies by Morel (17) demonstrated that the response of adenylate cyclase to vasopressin in medullary thick ascending limb is lacking in human and dog kidneys, but it is present in rat, rabbit, and mouse kidneys. Considering these species differences, it is critically important to know if a protein that is homologous to rAQP-CD is present in human kidney collecting duct.

Congenital nephrogenic diabetes insipidus (NDI) is a rare inherited disorder characterized by renal unresponsiveness to vasopressin. Most cases of NDI appear to have an X-linked recessive pattern of inheritance. Very recently several mutations in vasopressin $V_{2}$ receptor gene, which is located in chromosome $\mathrm{X}$, have been found in these patients as underlying mechanisms (18-21). However, NDI patients who did not show such an inheritance $(22)$, or whose $V_{2}$ receptor did not show any abnormality (20), have been reported, suggesting the presence of other gene abnormalities in some cases of NDI. Since AQP-CD is so critically important for urinary concentra-

1. Abbreviations used in this paper: $\mathrm{AQP}-\mathrm{CD}$, aquaporin of collecting duct; CHIP28, channel integrate protein of $28 \mathrm{kD}$; FISH, fluorescent in situ hybridization; h, human; MIP, major intrinsic protein of the bovine lens fiber membrane; NDI, nephrogenic diabetes insipidus; $r$, rat. 
tion, it is reasonable to speculate that a defect in this protein would also cause NDI.

In this study we examined whether an homologous protein to $\mathrm{rAQP}-\mathrm{CD}$ is present in human kidney. By screening the human kidney cDNA library, we isolated a cDNA clone that encodes a protein that is $91 \%$ identical to rAQP-CD, and named it human (h)AQP-CD. Studies showed that hAQP-CD was functionally and morphologically a homologous protein to rAQP-CD. Chromosomal mapping of hAQP-CD gene assigned its location to chromosome 12 .

\section{Methods}

Approximately $3 \times 10^{5}$ plaques of human kidney cDNA library in $\lambda$ Max 1 (Clonetech, Palo Alto, CA) were screened using rAQP-CD cDNA as a probe under stringent conditions: hybridization in $6 \times$ SSPE, $50 \%$ formamide at $42^{\circ} \mathrm{C}$, washing in $2 \times \operatorname{SSC}, 0.5 \%$ SDS at $42^{\circ} \mathrm{C}$. Positive clones were excised and converted into pYEUra 3 vector by helper phage. Several clones $(0.8-1.5 \mathrm{~kb})$ were isolated, and two clones with inserts of $1.5 \mathrm{~kb}$ were subcloned into the EcoRI site of the pSPORT vector (GIBCO BRL, Gaithersburg, MD). The pSPORT subclones of BamHI, KpnI, PstI, and SphI restriction fragments were sequenced by the Sanger dideoxynucleotide chain termination method using Sequenase (U.S. Biochem. Corp., Cleveland, OH). T7 and M13 sequencing primers and eight synthetic oligonucleotide primers were used for sequencing both strands of hAQP-CD.

For Northern blot analysis, RNA was extracted from the cortex and medulla of human kidney (nephrectomized for kidney tumor) by acid guanidine phenol chloroform method, and $30 \mu \mathrm{g}$ of total RNA per lane was subjected to electrophoresis on agarose gel containing formaldehyde. Equal loading was confirmed by staining with ethidium bromide. After transfer to a nylon membrane, blots were hybridized with the $\mathrm{hAQP}-\mathrm{CD}$ cDNA labeled with ${ }^{32} \mathrm{P}$ and autoradiographed for $24 \mathrm{~h}$.

Immunohistochemical study was performed to localize hAQP-CD protein in human kidney. Sequence comparison showed that only one amino acid ( $\mathrm{Thr} 265$ ) was different between human and rat $15 \mathrm{COOH}$ terminal amino acid, where we previously raised the polyclonal antibody against $\mathrm{rAQP}-\mathrm{CD}$ (Fig. 1). We therefore examined the antibodies for $\mathrm{rAQP}-\mathrm{CD}(8)$, but the stainings were weak and nonspecific staining was observed. Accordingly, we raised a new polyclonal antibody against a synthetic peptide (VELHSPQSLPRGTKA; Peptide Institute Inc., Minoh, Osaka) corresponding to the $15 \mathrm{COOH}$-terminal amino acid of $\mathrm{hAQP}-\mathrm{CD}$, in rabbits. The same kidney used for Northern analysis was used for immunohistochemical study. The kidney tissues were fixed in $2 \%$ paraformaldehyde solution, and thin cryostat sections (4 $\mu \mathrm{m})$ were made and mounted on slide glasses. The slides were preincubated with nonimmune goat serum; then they were rinsed and incubated with the rabbit serum ( $1: 500$ dilution ) at $37^{\circ} \mathrm{C}$ for $1 \mathrm{~h}$. Next, after being rinsed the slides were incubated for $1 \mathrm{~h}$ at $37^{\circ} \mathrm{C}$ with FITC-conjugated goat anti-rabbit immunoglobulins at 1:100 dilution.

Western blot analysis was performed using the same antibody as used for immunohistochemical studies. Membranes were prepared from human and rat kidneys by homogenization in a Potter Elvehjem apparatus. After homogenization in $10 \mathrm{vol}$ of $0.32 \mathrm{M}$ sucrose, $5 \mathrm{mM}$ Tris- $\mathrm{HCl}, 2 \mathrm{mM}$ EDTA, $0.1 \mathrm{mM}$ phenylmethylsulphonyl fluoride, 1 $\mu \mathrm{g} / \mathrm{ml}$ leupeptin, $1 \mu \mathrm{g} / \mathrm{ml}$ pepstatin $\mathrm{A}$, two centrifugations ( $10 \mathrm{~min}$, $1,000 \mathrm{~g}$ ) were applied. The supernate was then centrifuged at $250,000 \mathrm{~g}$ for $30 \mathrm{~min}$, and the pellet was suspended in the same buffer. The samples were solubilized in a sample loading buffer; $3 \%$ SDS, $65 \mathrm{mM}$ Tris- $\mathrm{HCl}, 10 \%$ glycerol, 5\% 2-mermercaptoethanol, and heated at $70^{\circ} \mathrm{C}$ for $5 \mathrm{~min}$. They were separated by SDS-PAGE using $10 \%$ polyacrylamide gels according to Laemmli (23), and were transferred to polyvinyl membranes (Immobilon; Millipore Corp., Bedford, MA). The blots were incubated with antisera (1:100 dilution), and were visualized using a ${ }^{125}$ I-protein A (ICN Biochemicals, Costa Mesa, CA). A urine sample from a healthy volunteer was concentrated 10 times by ultrafiltration (cutoff at 3,000 mol wt, Microcon-3; Amicon Corp., Danvers, MA), and was applied to SDS-PAGE as described above.

Functional expression study in $X$. oocytes was performed as described previously (8). Briefly, in vitro transcribed and capped RNA (cRNA) was injected into oocytes, followed by incubation for 24-48 h at $18^{\circ} \mathrm{C}$. Osmotic water permeability was calculated by the volume increase when oocytes were transferred from 200 to $70 \mathrm{mOsm} / \mathrm{kg}$ modified Barth's solution, at $20^{\circ} \mathrm{C}$. The volume increase was monitored by videomicroscopy and was analyzed by an image analysis system (C3163; Hamamatsu Photonics, Hamamatsu).

Chromosomal mapping was performed using a fluorescence in situ hybridization (FISH) method. Replicated prometaphase R-banded chromosomes were prepared from human lymphocytes. Two genomic lamda phage clones $(\sim 15 \mathrm{~kb})$ were isolated from a human genomic DNA library (Strategene, La Jolla, CA) using cDNA of hAQP-CD as a probe, and labeled by nick translation using biotin-16-dUTP (GIBCO $B R L)$. In situ hybridization was done as previously described (24) and detected by avidine-FITC conjugate (GIBCO BRL). To the genomic probes, 5-10 times excess amounts of sonicated total human placenta DNA were added for the elimination of repetitive sequences. When using cDNA of hAQP-CD as a probe, the intensity of the FITC was amplified according to the procedure reported by Hori et al. (25). Fluorescent signals on chromosome counterstained with propidium iodide were observed by a Nikon Microphot microscope (FXA-RFL) using filter combinations of B-2A for R-banded and UV-2 for Gbanded chromosomes.

\section{Results}

Sequencing of cDNA clones obtained from human kidney cDNA library indicated that two clones coded the same sequence of $1.5 \mathrm{~kb}$, and these clones were named hAQP-CD. The longest open reading frame encoded a 271-amino acid protein $\left(28,968 M_{\mathrm{r}}\right)$ that was highly homologous to $\mathrm{rAQP}-\mathrm{CD}$. In Fig. 1 , amino acid sequences of hAQP-CD, rAQP-CD, and human CHIP28 are compared. Sequence identity of hAQP-CD to rAQP-CD is $91 \%$, and to human CHIP28 is $48 \%$. The high homology of hAQP-CD to $\mathrm{rAQP}-\mathrm{CD}$ indicated that hAQP-CD is a human counterpart of $\mathrm{rAQP}-\mathrm{CD}$. The hydropathy profile of $h A Q P-C D$ was also very similar to that of $r A Q P-C D$; the profile predicts six membrane-spanning domains (8). The conserved amino acid sequence, named NPA box, and tandem repeat in the sequence, which are characteristics of MIP family $(13,14)$, were also conserved in hAQP-CD.

One potential $\mathrm{N}$-glycosilation site is present in the sequence of hAQP-CD (Asn 123), and one phosphorylation site (26) for protein kinase $A$ (Ser256), which was observed in $\mathrm{AQQP}-\mathrm{CD}$, is conserved in $\mathrm{hAQP}-\mathrm{CD}$.

Northern blot analysis of mRNA from the cortex and medulla of human kidney showed that the expression is predominant in the medulla (Fig. 2). The major transcript was $4.2 \mathrm{~kb}$, and another small band was detected at $1.6 \mathrm{~kb}$. This pattern was somewhat different from that of $\mathrm{rAQP}-\mathrm{CD}$. In $\mathrm{rAQP}-\mathrm{CD}$ the major band was $1.5 \mathrm{~kb}$, and faint bands at 2.8 and $4.4 \mathrm{~kb}$ were observed (8). Since our 1.5-kb cDNA clone of hAQP-CD coded a protein that is homologous to $\mathrm{rAQP}-\mathrm{CD}$, and since the predicted size of the protein $\left(28,968 M_{\mathrm{r}}\right)$ was observed in Western blot ( see below), we speculate that the larger band at $4.2 \mathrm{~kb}$ may represent polyadenylation variants.

Immunohistochemical study of the medulla of human kidney showed that the fluorescent staining was localized to only collecting duct cells (Fig. $3 a$ ). The staining was strong around the apical and subapical domains at higher magnification (Fig. $3 b$ ). Occasionally a faint band was observed on the basolateral 


\begin{tabular}{|c|c|c|c|c|c|c|c|c|}
\hline hWCH-CD & 1 & MWEIRSIAFS & RAVEAEELAT & LIFVFFGLGS & AI. & WATAP P SVIQ & 43 & \\
\hline IWCB-CD & 1 & MWELRS I AFS & RAVLAEFIAT & ILFVFF GIGS & AI & WAS SPP SVIQ & 43 & \\
\hline CHIP 28 & 1 & MASEF K KRLFW & RAVVAEFLAT & TIFVFISIGS & A LGFKYPVGN & N QT AVQDNVK & 51 & \\
\hline hWCB-CD & 44 & I AMAEGLGIG & TIVQALGHIS & GAHINPAVTV & ACLVGCHVSE & LRAAFYVAAQ & 93 & \\
\hline IWCB-CD & 44 & I AVAFGIGIG & IIVQALGHVS & GAH INPAVTV & ACLVGCHVSF & LRAAFYVAAQ & 93 & \\
\hline CAIP 28 & 52 & VSIAFGLSIA & TLAQS VGHIS & GA HLNPAVTL & GILL SCQISI & FRAL MY I IA Q & 101 & \\
\hline hWCH-CD & 94 & II GAVAGAAL & IAEITPADIR & GDLAVNAISN & STTAGQAVTV & ELFLTLQLVI & 143 & \\
\hline IWCB-CD & 94 & IIGAVAGAAI & LHEI T PVEI R & GDLAVNATHN & NATAGQAVTV & ELFLTMQLVI & 143 & \\
\hline CAIP 28 & 102 & CVGAIVATAI & LSGITSSITG & N SIG RNDLAD & GVN SG QGI GI & EI I GTLQLVL & 151 & \\
\hline מพCB-CD & 144 & CIFASTDERR & GENPGTPAIS & I GF SVALGHL. & IS G IHYT GCSM & NPARSIAPAV & 193 & \\
\hline IWCB-CD & 144 & CIFASTDERR & GDNLGSPAIS & I GF SVT I GHI & IS G IY FTGCSM & NPARSLAPAV & 193 & \\
\hline CВIP 28 & 152 & CV LATTDRRR & RDI GGSA PIA & I GLSVALGHL & IAIDYTGCGI & NPARSF GSA V & 201 & \\
\hline hWCB-CD & 194 & VTGKFDDHWV & FWI GPIVGAI & LGSLLYNYVI. & FPPAKSISER & LAVLKGLEPD & 243 & \\
\hline IWCB-CD & 194 & VTGKFDDHFV & FWI GPIVGAI & I GSLIYNYLI & IPSAKSLQER & LAVLKGLEPD & 243 & \\
\hline CAIP 28 & 202 & ITH NF S NH KI & I WV G PF IGG A & LA VLIYDF IL & APRSSDLT DR & VNVWTSGQVE & 251 & \\
\hline & & & & & & & & $\begin{array}{l}\text { Figure } 1 \text {. The amino acid sequences } \\
\text { of hAOP-CD, and its comparison }\end{array}$ \\
\hline LWCB-CD & 244 & T DWEEREVR & RRQSVELHSP & QSIPRGTKA & & & 271 & to $\mathrm{rAQP}-\mathrm{CD}$ and human CHIP28. \\
\hline $\begin{array}{l}\text { IWCH-CD } \\
\text { CBTP28 }\end{array}$ & $\begin{array}{l}244 \\
252\end{array}$ & $\begin{array}{l}\text { DWEEREVR } \\
\text { E YDIDADDIN }\end{array}$ & RRQSVELHSP & QSLPRGSKA & & & 271 & $\begin{array}{l}\text { to } \mathrm{TAQP}-\mathrm{C} \text { and numaed residues are shaded. } \\
\text { Conserved }\end{array}$ \\
\hline CEIP 28 & 252 & E YDIDADDIN & SRVEMKPK & & & & 269 & Conserved residues are shaded. \\
\hline
\end{tabular}

membrane. In the cortex the staining was also restricted to collecting duct cells, and no signal was detected in proximal tubules and glomerulus (Fig. $3 c$ ). A close inspection indicated that a minority of the cortical collecting duct cells stained negatively, indicating that these cells may be intercalated cells. Intercalated cells are known not to express water channels (3). When the antibody was preincubated with the corresponding peptide immunogen, no specific staining was observed (data not shown). These results were the same as observed in the rat (8).

Western blot analysis was performed to determine the molecular mass of $\mathrm{hAQP}-\mathrm{CD}$ protein. Using the antibody against $\mathrm{hAQP}-\mathrm{CD}$, two bands were observed in the membrane preparation from human kidney medulla: a sharp band at $29 \mathrm{kD}$, and a diffuse band at 40-50 kD (Fig. 4, lane 4). This staining pattern is quite similar to that of CHIP28, in which a sharp band at 28 $\mathrm{kD}$ and a diffuse, higher molecular mass band at $35-55 \mathrm{kD}$ have been observed $(12,27)$. The latter diffuse band was shown to represent a glycosilated form of the $28-\mathrm{kD}$ protein

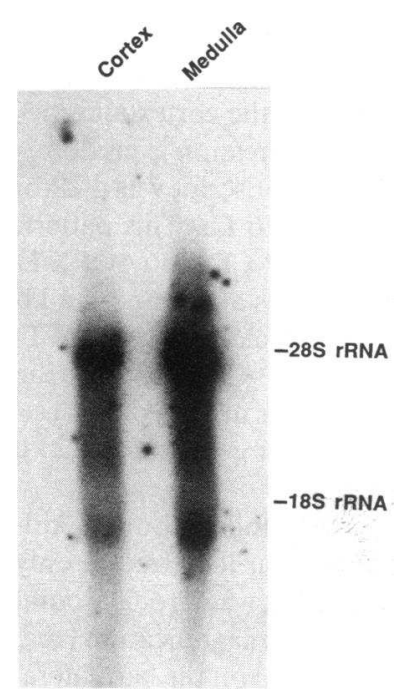

Figure 2. Northern blot analysis of expression of $\mathrm{hAQP}-\mathrm{CD}$ mRNA in human kidney. Total RNA was extracted from human kidney cortex and medulla, and $30 \mu \mathrm{g}$ per lane was subjected to electrophoresis.
(12). As shown in Fig. 5, after $\mathrm{N}$-glycanase digestion of human kidney medulla membranes, the high molecular mass band disappeared, demonstrating that the high molecular mass band represents a glycosilated form of the $29-\mathrm{kD}$ protein. In addition to the $29-\mathrm{kD}$ band, a smaller band $(\sim 26 \mathrm{kD})$ was noted after the N-glycanase treatment. The nature of this band is unknown, but may represent a degradated product of the 29-kD protein. Comparison between the cortex and medulla samples clearly indicated the dominant presence of $h A Q P-C D$ protein in the medulla (Fig. 4, lanes 3 and 4). Interestingly, the concentrated human urine contained a $29-\mathrm{kD}$ protein and a smaller band indicative of degradated proteins (Fig. 4, lane 5 ). These results indicate that some of hAQP-CD becomes detached from the apical membrane and is excreted in the urine. Blots stained with preimmune serum did not show any staining (Fig. 4, lanes 1 and 2). Rat kidney medulla membrane fraction was also subjected to the same Western blot analysis (Fig. 4, lane 6). The staining pattern was similar to that of human kidney medulla. The $29-\mathrm{kD}$ protein was observed at the same position in rat medulla, but a diffuse band distributed over a slightly smaller size region ( $36-45 \mathrm{kD}$ ) in the rat, indicating the difference in glycosilation.

To confirm that hAQP-CD works as a water channel, expression of in vitro transcribed mRNA (cRNA) of hAQP-CD in $X$. oocytes was examined. The determined osmotic water permeability coefficient $\left(P_{\mathrm{f}}\right)$ when oocytes were exposed to osmotic gradients was six times higher in cRNA-injected (40 $\mathrm{ng}$ ) oocytes than that of water-injected oocytes (122.2 $\pm 9.1 \mathrm{vs.}$ $19.8 \pm 1.5 \times 10^{-4} \mathrm{~cm} / \mathrm{s}$, mean $\left.\pm \mathrm{SE} ; P<0.05\right)$. The increase in $P_{\mathrm{f}}$ of hAQP-CD-injected oocytes was partially inhibited by a 5-min pretreatment with $0.3 \mathrm{mM} \mathrm{HgCl}$, an inhibitor of water channels (70.4 $\pm 2.8 \times 10^{-4} \mathrm{~cm} / \mathrm{s}$; Fig. 6$)$.

To determine the chromosomal location of hAQP-CD gene, we performed direct R-banded FISH studies on prometaphase chromosome spreads using two different genomic probes (both were $\sim 15 \mathrm{~kb}$ in size). A total of 41 prometaphases were analyzed for the presence of fluorescent spots of both probes. The hybridization signals showing twin spots on both sister chromatids were observed at chromosome band $12 \mathrm{q} 13.75 \%$ of 

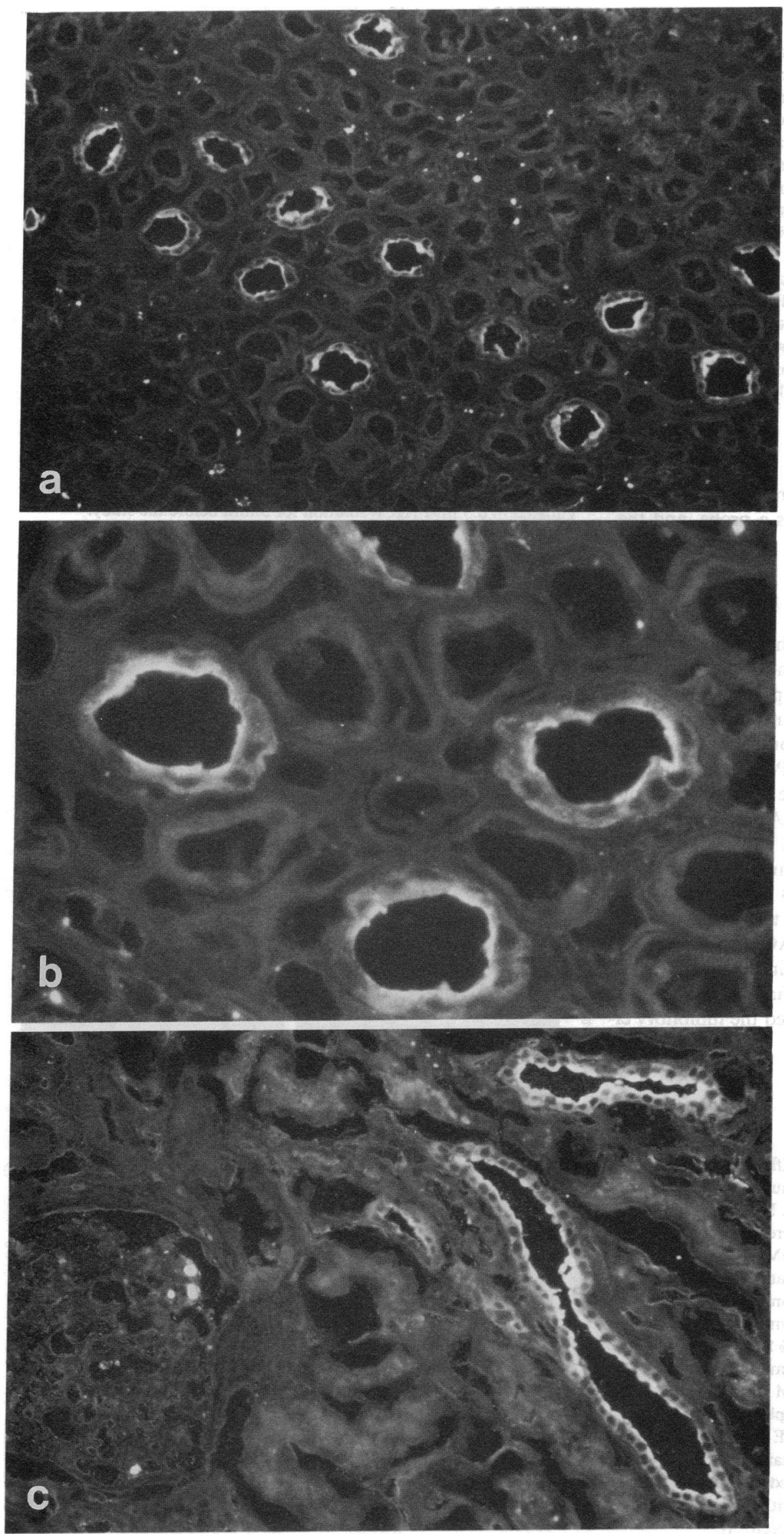

Figure 3. Immunohistochemical localization of hAQP-CD in human kidney. Thin sections of human kidney were incubated with rabbit polyclonal antibody against the $\mathrm{COOH}$ terminal of $\mathrm{hAQP-CD}$ and visualized by FITC-conjugated goat anti-rabbit immunoglobulins. ( $a$ ) Medulla, $\times 40$; $(b)$ medulla, $\times 100$; and $(c)$ cortex, $\times 40$. 


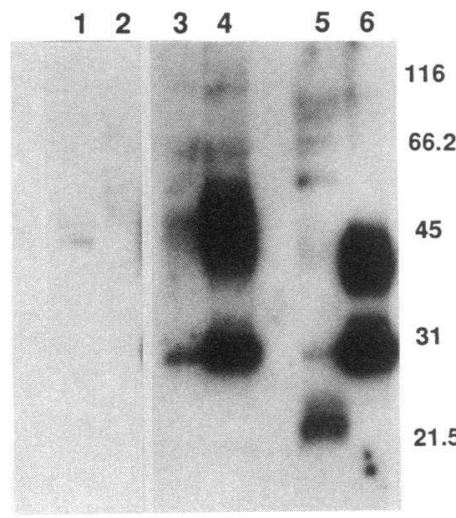

16

66.2

31

transfer to the membrane blots were incubated with antiserum (lanes 3-6) or

with preimmune serum (lanes 1 and 2 ). A rat kidney medulla membrane sample was also applied $(10 \mu \mathrm{g})$ in lane 6.

the signals were on the $12 \mathrm{q} 13.11-\mathrm{q} 13.12$ region (Fig. 7). In addition, cDNA of hAQP-CD was used as a probe, and the result was identical.

\section{Discussion}

The presence of hAQP-CD, which is highly homologous to rAQP-CD in terms of amino acid sequence, localization of both mRNA and protein, and functional expression in oocytes, strongly suggests that AQP-CD is important for urinary concentration in many mammalian species. Comparison of amino acid sequences among hAQP-CD, rAQP-CD, and human CHIP28 may provide some insight into the functional characteristics of AQP-CD. In the sequence of hAQP-CD, there are four cysteine residues (at 75, 79, 144, and 181) that could be important for water channel function, because $\mathrm{HgCl}_{2}$ has been known as an inhibitor of water channels (28). All residues except Cys 75 are conserved among these three proteins, and Cys75 is conserved in hAQP-CD and rAQP-CD. Cys 181 is conserved in these three proteins, but not in other MIP family members. Preston et al. (29) have shown that site-directed mutagenesis of this cysteine to serine abolished the inhibitory ef-

1

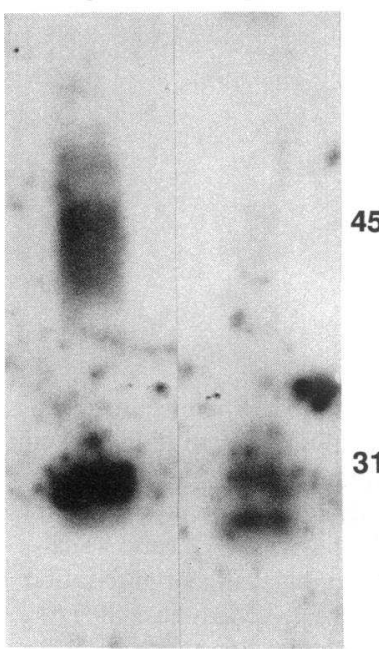

Figure 5. Effect of N-glycanase digestion of human kidney medulla membrane. Membrane aliquots $(40 \mu \mathrm{g})$ were denatured in $0.5 \%$ SDS, $50 \mathrm{mM} \beta$-mercaptoethanol, then incubated for $20 \mathrm{~h}$ at $37^{\circ} \mathrm{C}$ in $75 \mu$ l containing $1 \mathrm{U} \mathrm{N}$-glycanase (Genzyme Corp., Cambridge, MA), $0.2 \%$ SDS, $1.3 \%$ NP-40, 150 mM sodium phosphate ( $\mathrm{pH} 7.5)$, and $10 \mathrm{mM} 1,10$ phenanthroline (39). Samples were analyzed by SDS-PAGE immunoblot. Lanes 1 and 2 contained $15 \mu \mathrm{g}$ of human kidney medulla membrane without and with $\mathrm{N}$-glycanase treatment, respectively.

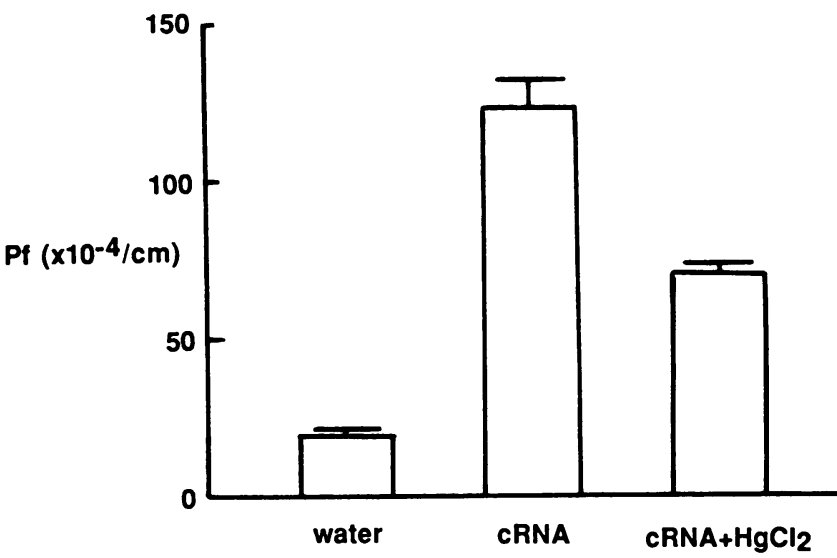

Figure 6. Functional expression of cRNA of AQP-CD in $X$. oocytes. Oocytes were injected with $40 \mathrm{nl}$ water or $40 \mathrm{ng}$ hAQP-CD cRNA, and incubated for $24-48 \mathrm{~h}$ at $18^{\circ} \mathrm{C}$. Osmotic water permeability $\left(P_{f}\right)$ was determined by measuring the hypotonic volume increase at $20^{\circ} \mathrm{C}$. For inhibition by mercurial sulphydryl agent, oocytes were incubated in $0.3 \mathrm{mM} \mathrm{HgCl}_{2}$ solution for $5 \mathrm{~min}$ before the study.
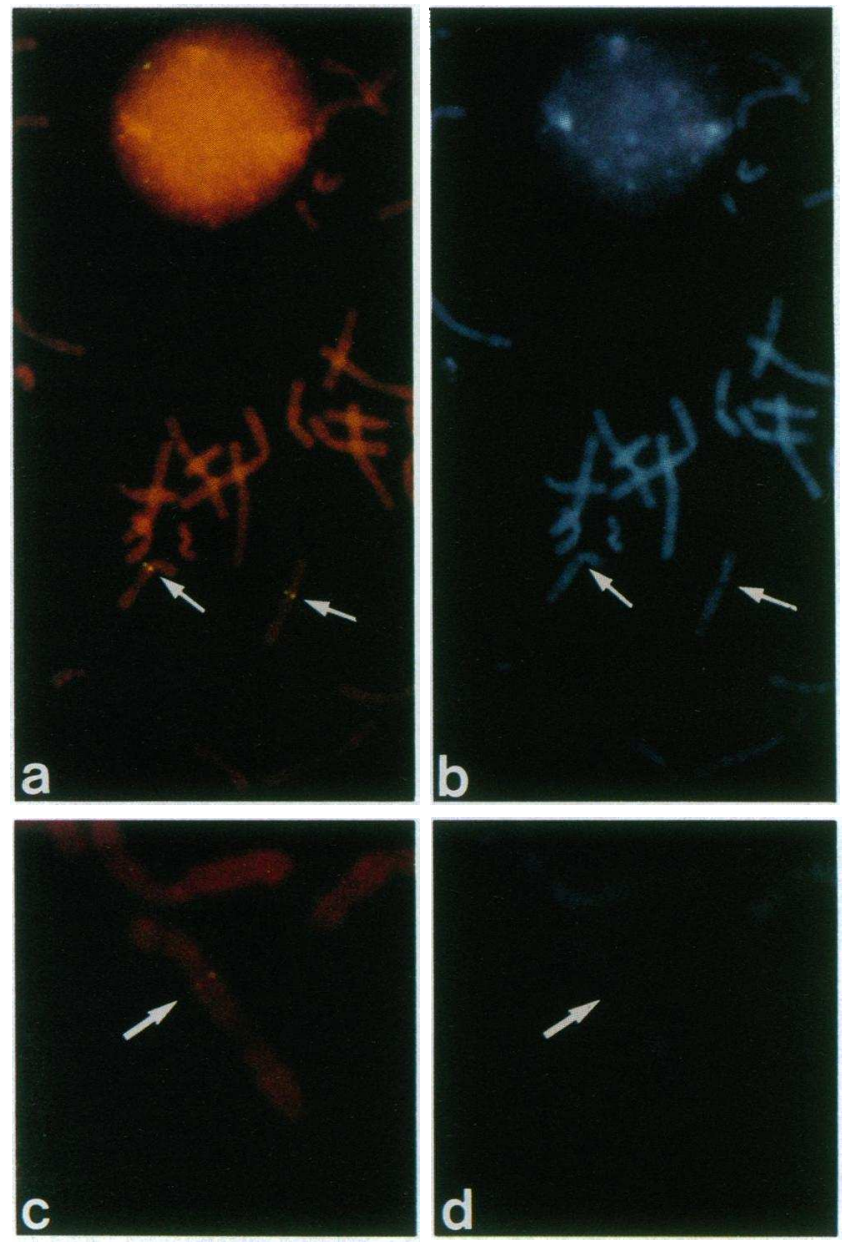

Figure 7. Chromosomal mapping of hAQP-CD gene. Fluorescence in situ hybridization on chromosomes from human cultured lymphocytes with genomic DNA clones $(\sim 15 \mathrm{~kb})$ were performed. Fluorescent signals were observed at the 12q13.11-q13.12 region (arrows). $(a$ and $c$ ) R-banded chromosomes (Nikon B-2A filter). ( $b$ and $d$ ) Gbanded chromosomes (Nikon UV-2A filter). 
fect of mercury. These results taken together indicate that this cysteine residue is critically important for water channel function.

The cytosolic domain of the $\mathrm{COOH}$ terminal of AQP-CD (48 amino acids) lacks homology to CHIP28 (12.5\%), and may contribute to a specific character of AQP-CD. When we cloned $\mathrm{rAQP}-\mathrm{CD}$, we found a consensus sequence for phosphorylation by protein kinase $\mathrm{A}$ in the $\mathrm{COOH}$ terminal (8). This sequence is conserved in $\mathrm{hAQP}-\mathrm{CD}$, but not in CHIP28. It is fascinating to speculate that protein kinase A directly phosphorylates AQP-CD protein to alter the water channel function. This speculation is not unrealistic, because it has been reported that protein kinase A phosphorylates MIP (30-32) and alters the voltage-dependent character of the channel function of MIP (33). If this is the case in AQP-CD, then this process will provide another mechanism other than the shuttle hypothesis, for rapid regulation of water permeability of collecting duct by vasopressin. The shuttle hypothesis explains the rapid regulation of water permeability by exo- and endocytosis of water channel-containing endocytic vesicles to and from the apical membrane $(3,4,6,7,34)$. A possibility of direct phosphorylation by protein kinase $A$ will be answered in the near future.

Western blot analysis showed that hAQP may be composed of two molecular mass forms: a sharp band of $29 \mathrm{kD}$ and a broad band of $\sim 40 \mathrm{kD}$. A similar study in CHIP28 gave the similar pattern to ours, in which a broad band was shown to be a glycosilated form of $28 \mathrm{kD}$ protein (12). The study of N-glycanase digestion (Fig. 5) clearly showed that the broad high molecular mass band in hAQP-CD is a glycosilated form of the 29-kD protein. The sequence of $\mathrm{hAQP}-\mathrm{CD}$ also has a potential site for $\mathrm{N}$-glycosylation. The amino acid sequence of hAQPCD predicts a 28,968-dalton protein, which is consistent with a band at $29 \mathrm{kD}$. The antibody against $\mathrm{hAQP}-\mathrm{CD}$ used in this study stained rAQP-CD to the same extent. Comparison of hAQP-CD and rAQP-CD in the same gel (Fig. 4) showed that the molecular mass of AQP-CD is the same in human and rat (29 kD).

It is interesting to observe the presence of the $29-\mathrm{kD}$ intact form of hAQP-CD in the urine of a normal subject. This indicates that hAQP-CD in the apical membrane of collecting duct becomes detached from the membrane and is excreted into the urine. Since there may not be much protease activity and protein-absorbing ability in the collecting duct, ureter, and bladder, it is likely that AQP-CD, once detached from the membrane, will be excreted in an intact form. This result raises a possibility that hAQP-CD can be used as a marker of the damage to collecting duct cells.

There are two types of congenital NDI (35). Type I (MIM 304800 ) is an X-linked disease whose defect concerns the inability of renal tubule to respond to vasopressin, and in this patient administration of vasopressin is not followed by an increase in urinary cAMP (36). Another one is type II (MIMI 125800 ), an autosomal dominant disease in which urinary levels of cAMP are elevated in response to vasopressin $(37,38)$. Recently, the cause of X-linked NDI has been identified as a defect in vasopressin $V_{2}$ receptor gene, which locates in the $X$ chromosome (18-21). However, NDI patients who did not show X-linked inheritance (22), or whose V2 receptor gene was not abnormal (20), have been also reported.

The apical membrane water channel plays a pivotal role in water absorption in the collecting duct. It can be anticipated that if the function of this protein is disturbed, it will cause NDI. This form of defect predicts a lack of diuretic response to vasopressin accompanied by an intact response of cAMP generation. It might be possible that abnormalities in the hAQP-CD gene exist in type II patients. Thus, the locus of the hAQP-CD gene (chromosome 12q13) might be identical to that of NDI type II. Clearly, this possibility awaits future studies.

\section{Acknowledgment}

This study was supported by a grant from the Salt Science Research Foundation, a grant-in-aid from the Ministry of Education, Science and Culture, Japan, and Special Coordination Funds of the Science and Technology Agency of the Japanese Government.

\section{References}

1. Smith, H. W. 1953. From Fish to Philosopher. Little, Brown and Company, Boston. 264 pp.

2. Orloff, J., and J. S. Handler. 1967. The role of adenosine 3,5-phosphate in the action of antidiuretic hormone. Am. J. Med. 42:757-768.

3. Handler, J. S. 1988. Antidiuretic hormone moves membranes. Am. J. Physiol. 255:F375-F382.

4. Harris, H. W., and J. S. Handler. 1988. The role of membrane turnover in the water permeability response to antidiuretic hormone. J. Membr. Biol. 103:207-216.

5. Al-Zahid, G., J. A. Schafer, S. L. Troutman, and T. E. Andreoli. 1977 Effect of antidiuretic hormone on water and solute permeation, and the activation energies for these processes, in mammalian cortical collecting tubules. $J$. Membr. Biol. 31:103-129.

6. Harris, H. W., K. Strange, and M. L. Zeidel. 1991. Current understanding of the cellular biology and molecular structure of the antidiuretic hormone stimulated water transport pathway. J. Clin. Invest. 88:1-8.

7. Verkman, A.S. 1989. Mechanisms and regulation of water permeability in renal epithelia. Am. J. Physiol. 257:C837-C850.

8. Fushimi, K., S. Uchida, Y. Hara, Y. Hirata, F. Marumo, and S. Sasaki. 1993. Cloning and expression of apical membrane water channel of rat kidney collecting tubule. Nature (Lond.). 361:549-552.

9. Gorin, M. B., S. B. Yancey, J. Cline, J. P. Revel, and J. Horwitz. 1984. The major intrinsic protein (MIP) of the bovine lens fiber membrane: characterization and structure based on cDNA cloning. Cell. 39:49-59.

10. Preston, G. M., and P. Agre. 1991. Isolation of the cDNA for erythrocyte integral membrane protein of 28 kilodaltons: member of an ancient channel family. Proc. Natl. Acad. Sci. USA. 88:11110-11114.

11. Preston, G. M., T. P. Carroll, W. B. Guggino, and P. Agre. 1992. Appearance of water channels in Xenopus oocytes expressing red cell CHIP28 protein. Science (Wash. DC). 256:385-387.

12. Denker, B. M., B. L. Smith, F. P. Kuhajda, and P. Agre. 1988. Identification, purification, and partial characterization of a novel Mr 28000 integral membrane protein from erythrocytes and renal tubules. J. Membr. Biol. 263:1563415642 .

13. Baker, M. E., and M. H. Saier. 1990. A common ancestor for bovine lens fiber major intrinsic protein, soybean nodulin-26 protein, and E. coli glycerol facilitator. Cell. 60:185-186.

14. Wistow, G. J., M. M. Pisano, and A. B. Chepelinsky. 1991. Tandem sequence repeats in transmembrane channel proteins. Trends Biochem. Sci. 16:170-171.

15. MacMillen, R. E., and A. K. Lee. 1969. Water metabolism of Australian hopping mouse. Comp. Biochem. Physiol. 28:493-496.

16. Kritz, W., and B. Kaissling. 1992. Structural organization of the mammalian kidney. In The Kidney: Physiology and Pathophysiology. D. W. Seldin and G. Giebisch, editors. Raven Press, Ltd., New York. 707-777.

17. Morel, F. 1981. Site of hormone action in mammalian nephron. Am. J. Physiol. 240:F156-F164.

18. Lolait, S. J., A. O’Carroll, O. W. McBride, M. Konig, A. Morel, and M. J. Brownstein. 1992. Cloning and characterization of a vasopressin V2 receptor and possible link to nephrogenic diabetes insipidus. Nature (Lond.). 357:336-339.

19. Ouweland, A. M. W., J. C. F. M. Dreesen, M. Verdijk, N. V. A. M. Knoers, L. A. H. Honnens, M. Rocchi, and B. A. Oost. 1992. Mutations in the vasopressin type 2 receptor gene (AVPR2) associated with nephrogenic diabetes insipidus. Nature Genetics. 2:99-106.

20. Pan, Y., A. Metzenberg, S. Das, B. Jing, and J. Gitschier. 1992. Mutation in the V2 vasopressin receptor gene are associated with $\mathrm{X}$-linked nephrogenic diabetes insipidus. Nature Genetics. 2:103-106. 
21. Rosenthal, W., A. Seilbold, A. Antaramian, M. Lonergan, M.-F. Arthus, G. N. Hendy, M. Birnbaumer, and D. G. Bichet. 1992. Molecular identification of the gene responsible for congenic diabetes insipidus. Nature (Lond.). 359:233235.

22. Langley, J. M., J. W. Balfe, T. Selander, P. N. Ray, and J. T. R. Clarke. 1991. Autosomal recessive inheritance of vasopressin-resistant diabetes insipidus. Am. J. Med. Genet. 38:90-94.

23. Laemmli, U. K. 1970. Cleavage of structural proteins during assembly of the head of bacteriophage T4. Nature (Lond.). 227:680-685.

24. Takahashi, E., K. Yamakawa, Y. Nakamura, and T. Hori. 1992. A high resolution cytogenetic map of human chromosome 3: localization of 291 new cosmid markers by direct R-banding fluorescence in-situ hybridization. Genomics. 13:1047-1055.

25. Hori, T., E. Takahashi, D. Ayusawa, K. Takeishi, S. Kaneda, and T. Seno. 1990. Regional assignment of the human thymidylate synthase gene to chromosome band $18 \mathrm{pl} 1.32$ by nonisotopic in situ hybridization. Hum. Genet. 85:576580.

26. Kennelly, P. J., and E. G. Krebs. 1991. Consensus sequence as substrate specificity determinants for protein kinases and protein phosphatases. J. Biol. Chem. 266:15555-15558.

27. Smith, B. L., and P. Agre. 1991. Erythrocyte Mr 28,000 transmembrane protein exists as a multisubunit oligomer similar to channel proteins. J. Biol. Chem. 266:6407-6415.

28. Macey, R. I. 1984. Transport of water and urea in red cells. Am. J. Physiol. 246:C195-C203.

29. Preston, G. M., J. S. Jung, W. B. Guggino, and P. Agre. 1992. The mercury-sensitive residue at cystein 189 in the CHIP28 water channel. J. Biol. Chem. 268:17-20.
30. Garland, D., and P. Russell. 1985. Phosphorylation of lens fiber cell membrane proteins. Proc. Natl. Acad. Sci. USA. 82:653-657.

31. Johnson, K. R., P. D. Lampe, K. C. Hur, C. F. Louis, and R. G. Johnson 1986. A lens intracellular junction protein, MP26, is a phosphoprotein. J. Cell Biol. 102:1334-1343.

32. Lampe, P. D., and R. G. Johnson. 1990. Amino acid sequence of in vitro phosphorylation sites in the main intrinsic protein of lens membranes. Eur. J. Biochem. 194:541-547.

33. Ehring, G. R., N. Lagos, G. A. Zampighi, and J. E. Hall. 1991. Phosphorylation modulates the voltage dependence of channels reconstituted from the major intrinsic protein of lens fiber membranes. J. Membr. Biol. 126:75-88.

34. Wade, J. B., D. L. Stetson, and S. A. Lewis. 1981. ADH action: evidence for a membrane shuttle mechanism. Ann. NY Acad. Sci. 372:106-117.

35. McKusick, V. A. 1990. Mendelian Inheritance in Man. Johns Hopkins University Press, Baltimore. 2028 pp.

36. Bell, N. H., C. M. Clark, S. Avery, T. Sinha, C. W. Trygstad, and D. O. Allen. 1974. Demonstration of a defect in the formation of adenosine 3,5-monophosphate in vasopressin-resistant diabetes insipidus. Pediatr. Res. 8:223-230.

37. Zimmerman, D., and O. C. Green. 1975. Nephrogenic diabetes insipidus type II: defect distal to the adenylate cyclase step. Pediatr. Res. 9:381

38. Ohzeki, T., T. Igarashi, and A. Okamoto. 1984. Familial cases of congenital nephrogenic diabetes insipidus type II: remarkable increment of urinary adenosine 3,5-monophosphate in response to antidiuretic hormone. J. Pediatr. 104:593-595.

39. Nielsen, S., B. L. Smith, E. I. Christensen, M. A. Knepper, and P. Agre. 1993. CHIP28 water channels are localized in constitutively water-permeable segments of the nephron. J. Cell Biol. 120:371-383. 